\title{
The Role of Urban Green Areas in the Education for Sustainable Development: Focus on Krakow, Poland
}

\author{
Aleksandra Wagner ${ }^{1, *}$, Malgorzata Orlewicz-Musial ${ }^{2}$ \\ ${ }^{1}$ Department of Geoinformation, Photogrammetry and Remote Sensing of Environment, Faculty of Mining Surveying and \\ Environmental Engineering, AGH University of Science and Technology, Poland \\ ${ }^{2}$ Department of Geoinformation, Photogrammetry and Remote Sensing of Environment, University of Physical Education in Krakow, \\ Poland
}

Copyright $(\mathcal{C} 2015$ by authors, all rights reserved. Authors agree that this article remains permanently open access under the terms of the Creative Commons Attribution License 4.0 International License

\begin{abstract}
Four selected green areas in Krakow (Poland) were compared, including: (1) the historical centre of Krakow with the green belt of Planty; (2) Błonia - grassland situated near the city centre; (3) the Park of Aviators, situated between the old part of Krakow and the industrial district of Nowa Huta and (4) the Nowa Huta Meadows. All these areas have great potential educational values. All the aspects of sustainable development are important in their management. The environmental aspect means preserving biodiversity and filtering pollutants. The economic aspect is connected with the projects that bring economic profits, as well as in higher value of real estate situated near green areas. The areas are attended by the residents of Krakow, which contributes to social and well-being aspects. The educational value of green areas is related with the ability to observe nature as well as formal and informal meetings and sports and recreational activities allowing social integration in many fields. The questionnaire showed great importance of green areas for local residents.
\end{abstract}

Keywords Parks, Meadows, Sustainable Development, Educational Activities, Sports

\section{Introduction}

Sustainable development consists of three aspects: environmental, economic and social [1]. Atkinson [2] adds the forth aspect - wellbeing, making a compass consisting of four sides: Nature, Society, Economy and Wellbeing. Wellbeing however can also be understood as a quality referring to the three previously mentioned aspects. While the environmental role of urban green areas is unquestionable, economic and social roles are often understood as contradict to it and in big cities the remaining "empty" areas are built up with apartment buildings, supermarkets, and parks to satisfy the economic and social needs (jobs, housing, etc). This way green areas are shrinking.

Nevertheless growing popularity of sports and recreation makes local authorities take care about green areas treated as places of recreation. This idea (still without using the term "sustainable development") appeared at the end of $19^{\text {th }}$ century with the concept of "garden cities", designed to satisfy social and economic needs and create healthy environment for people (especially workers and their families, so far, having been living in appalling conditions) [3]. The effect of this policy was saving the existing green areas from the construction development, as well as converting brown fields into green fields. Social role of green areas remains as important as it was more than 100 years ago. Economic role for ordinary people can be seen in the aspect of allotments providing fruit and vegetables to their users, even though, growing vegetables in recent years became less important than recreational function of allotments [4].

Public green areas (parks, meadows) are often rented for mass events, bringing profit to the municipality and stimulating social life of the community. Parks and meadows can also play a great role in the education for sustainable development, both through organizing events particularly related to such education (e.g. Recycling Festival) or encouraging individual studies (e.g. through information tables at the didactic trails, bird watching, etc.).

The aim of this study is to look at the role of selected areas of the city of Krakow in the promotion of different aspects of sustainable development.

\section{Materials and Methods}

\subsection{Study Area}

For this paper four green areas in the city of Krakow were selected: 
1. Planty - a green belt surrounding the historical centre of Krakow;

2. Błonia Krakowskie - a grassland situated near the city centre;

3. the Park of Polish Aviators (Park Lotników Polskich), situated between the old part of Krakow and the industrial district of Nowa Huta;

4. the Nowa Huta Meadows (Laki Nowohckie).

In Krakow there are much more parks and green areas. These four were selected in such a way that they were representative for a certain type of vegetation and, consequently recreation activities: two typical parks with trees and two meadows. Two areas were situated in the so called "old Krakow" - Planty in the very historical centre and Błonia - about 1-2 km from the historical centre. The Nowa Huta meadows are also situated close to the Nowa Huta Central Square - 400m distance, which makes similarity to the Krakow Błonia. Nowa Huta is an industrial part of Kraków, built in 1950s around the newly built (in those times) steelworks, which in 1954 was named after Vladimir Lenin, in 1990 re-named after Tadeusz Sendzimir, now the official name is ArcelorMittal Poland S.A. Branch in Krakow (former T. Sendzimir Steelworks). Building the steelworks significantly changed the social structure of the population. The Steelworks and the residential area of Nowa Huta were built in the place of several villages. This resulted in expropriations of the farmers [5]. The inhabitants of Nowa Huta were mainly workers. Many of them came from the surrounding villages, often affected by expropriations. These people had to change their environment quite rapidly. The population structure of Nowa Huta significantly varied from the structure of the "old" Krakow, where intelligentsia played a very important role. These historic differences can be still visible and influence the approach to the environment and sustainable development in the examined areas.

The Park of Polish Aviators (Park Lotników Polskich), also called the Park of Aviators (Park Lotników), earlier the Park of Culture and Leisure (Park Kultury $i$ Wypoczynku) was established in 1966 as a green belt isolating Krakow from the Steelworks emissions. The area is crossed by a big road. In the northern part of the area there is the Museum of Aviation formed in the area of the old airport Czyżyny-Rakowice in 1964 [6]. The studied locations are given in fig.1.

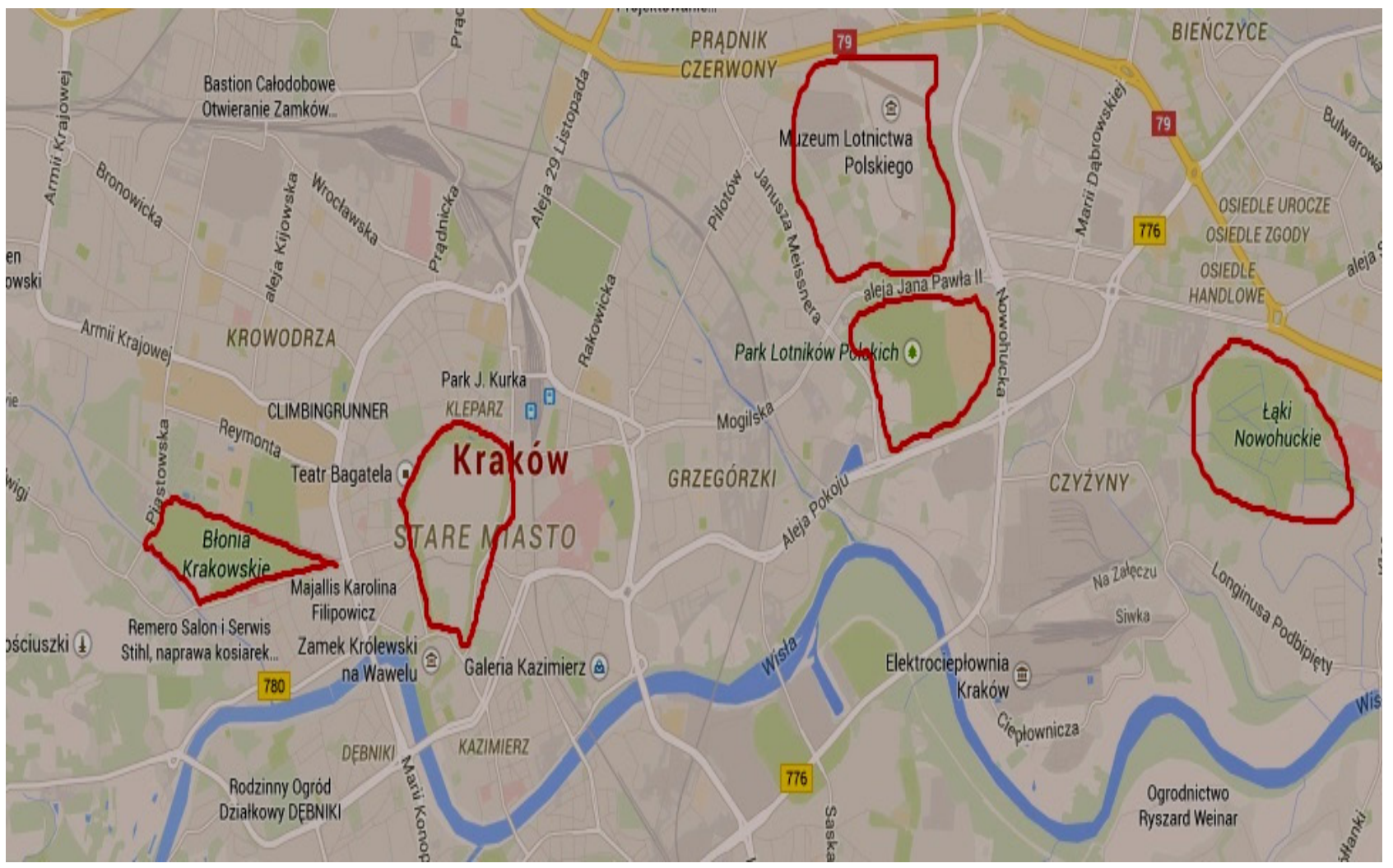

Figure 1. The study area. From west to east: Błonia, Planty, the Park of the Polish Aviators (with the area surrounding the Museum of Aviation - to the north), the Nowa Huta Meadows. Source: google maps - modified. 


\subsection{Methods}

The basic method applied in this paper was case study. The authors tried to assess the educational role of the green areas. Literature data, information from websites as well as the interviews with the visitors were used. In the two areas of Nowa Huta a questionnaire about the role of green areas was made in the Park of Polish Aviators and the Nowa Huta meadows. The survey was done $8^{\text {th }}$ and $10^{\text {th }}$ August 2014 (Friday and Sunday afternoons). The questionnaire referring to Planty was carried out on $5^{\text {th }}$ July 2015 (Sunday afternoon) and in Błonia the questionnaire was carried out on $14^{\text {th }}$ July 2015 (Tuesday afternoon). Any person above 15 years of age present there was asked to assess these areas and say about their activities carried out there. The significance of differences was checked by chi square. Some of the questionnaire results (referring to the Park of Polish Aviators and the Nowa Huta Meadows) were published earlier by the authors [6] and are also discussed in this paper.

\section{Results}

\subsection{Planty}

The green area of Planty (the word derived from "plantations") was established in late $18^{\text {th }}$ century in the place of the old city walls. The area was situated in the place of the old city walls. On $3^{\text {rd }}$ May 1792 (the first anniversary of the First Polish Constitution) in the northern part of the area, the Freedom Tree was planted (an elm tree - Ulmus sp.). This is regarded as a symbolic beginning of Planty. Between 1800-1801 in the northern part, a walking area was constructed, but the walls were not destroyed. In 1806 the decision to destroy all the walls to improve sanitary conditions in the city was made, but some parts were preserved. Feliks Radwański and Florian Straszewski were responsible for creating the area of Planty. The present shape is similar to the one of 19th century [7]. Apart from ecological values the park of Planty has also cultural and historical value. On $13^{\text {th }}$ May 1976 the area was listed as a historical monument and given no. A-576. In 1978 the Planty was put on the UNESCO World Heritage List (together with the Old Town of Krakow) [7, 8]. The view of Planty (north-western side) is shown in fig. 2.

The area would be potentially valuable for the education for sustainable development, due to the combination of different aspects of human life in one place, nevertheless the events held there are more concentrated on cultural and sports events (like the New Years' Eve Run).

\subsection{Błonia Krakowskie (the Krakow's Błonia)}

The Polish word "błonia" (used in plural) means an area covered by grass. It can be translated as "meadows", nevertheless in Krakow the name is used as a proper name, thus the authors decided not to translate it.
The area of Błonia (fig. 3.) is 48 ha. It is unique on the European scale that such a large area of meadows is situated less than $2 \mathrm{~km}$ from the strict city centre. Nowadays the area has different functions, suitable both for individual recreation and mass events related to sports, culture, charity, religious and patriotic celebrations [9], as well as smaller meetings with family and friends.

From time to time the plans to build up or re-arrange Błonia were considered. For example, during German occupation (1939-1945), there were serious plans to build a residential area in Błonia $[9,10]$. Some discussions about the development were also carried out later, in 1970s. None of these plans were implemented. On $7^{\text {th }}$ April 2000 Błonia Krakowskie were written into the list of historical monuments no. 132, A-1114, which effectively makes it impossible to build up the area $[8,9]$.

The size and location of Błonia make them an ideal place for mass cultural, sports, social and other events, including those strictly related to education for sustainable development. Since 2002 Recycling Festivals have been carried out in Błonia. They are organized in spring (in 2015 on 29-30 ${ }^{\text {th }}$ May) [11]. The idea of the Festival is providing information (in an attractive form, like games for children) about waste management, as well as giving the opportunity to bring recyclable materials and receive seedlings in exchange. This significantly contributes to the education for sustainable development. The area of Błonia is very good for this purpose due to the size as well as proximity to both densely inhabited areas as well as places of recreation, full of natural beauty. The area is visited by birds, occasionally also by the species included in the EU Bird Directive [12] - the white stork Ciconia ciconia (Brisson) [9] - fig. 4. The presence of this species was also confirmed by the questionnaire respondents (chapter 3.5).

\subsection{The Park of the Polish Aviators}

As mentioned in chapter 2.1., the Park of the Polish Aviators was established in 1966 . The name is related to the vicinity of the former Airport of Czyżyny and the Museum of Aviation, established in 1964. The city district of Czyżyny (XVIII) is situated between the "old" Kraków and Nowa Huta. In 1970s the buildings of the University of Physical Education were built. This made the Park the most obvious place of physical exercises for students (fig. 5). Some students' activities include cleaning the area from rubbish (fig. 6.), which gives the opportunity for education for sustainable development.

Another type of activities includes events organized in the Museum of Aviation, such as the Festival of the City District XVIII - Czyżyny. This event has many aspects: social, recreational and educational (fig. 7). Another interesting place in the Park is the Stanisław Lem Garden of Experiences (Ogród Doświadczeń im. Stanisława Lema), situated in the south eastern part of the Park. This is the place where children and adults can learn about physics and natural sciences [13]. 
Due to the activities of the groups promoting sports and recreation the citizens' project "Marking the jogging routes in the Park of the Polish Aviators (District XIV Czyżyny)" was accepted [14]. The sum of money given for the project is PLN 117160.82 (around Euro 29290) [15]. From the project three main groups will benefit: the students of the University of Physical Education, the Students of the Cracow University of Technology and the residents of the neighbouring blocks of flats.

There are plans to build a residential area in the direct vicinity of the park. The investors emphasize high quality of the environment (the Park), which means that the vicinity of green areas contributes to the attractiveness of the blocks of flats, which can raise their value [16].

\subsection{Nowa Huta Meadows}

The Nowa Huta Meadows (fig. 8) are situated south of the Nowa Huta Culture Centre. The area of 57.17 ha covers the old riverbed of the Vistula. Decision No. XV/100/03 of the City Council of Krakow, on 7th May 2003, pronounced this area Ecologically Useful Area (Uzytek Ekologiczny). The reason was the protection of semi-natural habitats such as wet meadows, fresh meadows, reed, sedges, as well as ruderal habitats. The area is also rich in fauna, especially birds, including the species of EU Bird Directive [6], such as the corn crake Crex crex (L.) and the red-backed shrike Lanius collourio L. The total number of bird species is 69 , including 34 nesting birds. Butterfly fauna is also rich and includes rare species [17]. There are didactic trails in the area, helping in the observations of nature (fig. 9). The meadows are also used as the area of physical education classes (the University of Physical Education is $3 \mathrm{~km}$ away), jogging, Nordic walking, as well as organized workshops related to nature observations. Such workshops are organized on the occasion of the Earth Days (usually the closest weekend to 22nd April), celebrated in the centre of Nowa Huta. The Earth Days have been organized since 2004 [18]. Events like the Recycling Festival give opportunity to exchange recyclable materials into seedlings. In 2015 the Earth Days were organized on $24-25^{\text {th }}$ April. One of the events included the Botanical Workshops at the Nowa Huta Meadows, organized by the C.K. Norwid Culture Centre (Ośrodek Kultury im. C.K. Norwida) [19]. The Meadows have also been the place of regular biology and ecology classes for the students of Tourism and Recreation of the J. Dietel Małopolska Vocational University in Krakow. The classes were carried out by Prof. Eugeniusz Dubiel, who is also the author of the Atlas of the Actual Vegetation of Krakow [20]. The Meadows are managed by the Foundation City Park and Zoological Garden in Krakow [17].

\subsection{Questionnaire Results}

There were 42 respondents ( 16 men, 25 women and one person failing to provide data) in Planty, 32 respondents (14 men. 17 women and one person failing to provide data) in
Błonia, 25 respondents (12 men and 13 women) in the Park of the Polish Aviators and 30 (13 men and 17 women) in the Nowa Huta Meadows. The age distribution of respondents is given in table 1 . There was a statistically significant difference between the places in terms of respondents' age $\chi^{2}$ $=32.24, \mathrm{df}=15, \mathrm{p}<0.01$. In most locations two groups were dominant: 25-34 years old and people of 65 and above pensioners - coming on their own or in couples. The least represented was the group of people between 45 and 55 years of age. The exception is Błonia, where this group is relatively large, while the group of 65 and above is smaller than in other locations. Table 2 shows the place of residence of the respondents of Planty and Błonia. There were no statistically significant differences between the locations. Significantly more visitors of the Nowa Huta Meadows came from Nowa Huta than it was in the case of the Park of Aviators $\chi^{2}=7.671$, $\mathrm{df}=1, \mathrm{p}<0.01$ (numbers shown in Table 3 ). Table 4 . shows the results of the assessment of the two places (in case of Nowa Huta the data are taken from the authors' previous paper [6]).

Table 4. shows the mean assessments of the places made by the visitors in different aspects. The scale 1-5 was applied ( 1 was the worst and 5 the best). The accessibility was generally highly graded. The highest grade was in Planty (4.67) and the lowest in the Nowa Huta meadows (4.23). The result can be affected by the road construction works taking place during the questionnaire in 2014. According to the respondents the best sports and recreational facilities were in the Park of Aviators (4.19) and the worst in Planty (3.27). On the other hand some visitors declined from the assessment of sports facilities in Planty saying they were not necessary in that place. Natural values (flora and fauna) were best graded in the Nowa Huta Meadows (4.5), which is not surprising, considering the status of this area. In the meadows of Błonia the grade was the lowest (3.55), despite occasional occurrence of relatively rare species (the white stork), seen by some visitors. The highest grade referring to the presence of interesting objects (mainly historical monuments, but not only them) was obviously related to the situation in the historic city centre. The lowest grade was given to the Nowa Huta Meadows (3.12). Although the neighbouring 60 years old buildings of the Central Square are registered as a historical monument named the Urban System of the Nowa Huta district, A-1132, registered on $30^{\text {th }}$ December 2004 [8], the residents do not consider them too interesting. The best grade for general maintenance of the area was given to the Park of Aviators (4.08) and the lowest in the Nowa Huta Meadows (3.19). People were complaining that the grass was not mowed frequently enough.

The highest mean grade regarding all the aspects was given to the Park of the Polish Aviators (3.994). A very similar, slightly lower grade was given to Planty (3.97). Lower grades were given to grasslands, such as Błonia (3.822) and the Nowa Huta Meadows (3.984). This can mean that people prefer classical parks to meadows or that the presence of interesting objects (the Museum of Aviation and the old Town of Krakow) was decisive. 
The activities carried out in the green areas are shown in table 5. Strolling is predominant activity in most locations, only in Błonia physical exercises are predominant. Walks with the dog were carried out in Błonia (where dogs are allowed to run without a leash) and the Nowa Huta Meadows. In Planty they were rarer and in the Park of Aviators did not occur during the questionnaire. In Planty passive forms of leisure are predominant.

Table 5. gives the answer to the question "What brought you here for the first time?". The answers were differentiated. In Planty the most common answer included "other", among that $41 \%$ of answers (17 people) the ones mentioning "looking for shade" or "looking for rest" were predominant. Among these people there were also homeless people living there in summer. 24\% of the respondents in Planty admitted that they got there by accident. In Błonia the largest number of people were brought by a mass event. In the Park of Aviators the largest number of respondents (28\%) remembered that their first visit was connected with cycling. Cycling was also important in the case of the Nowa Huta Meadows(30\%), nevertheless, in that place, the most common answer was "I live here".

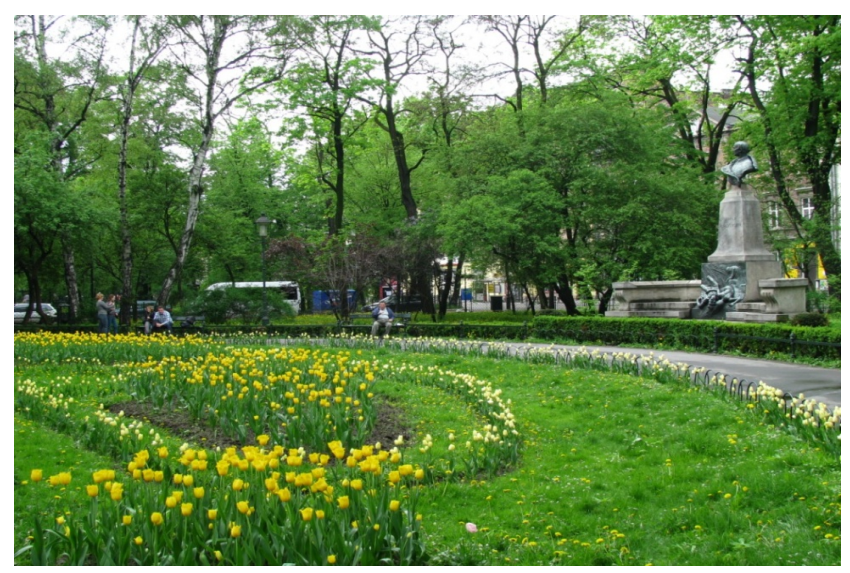

Figure 2. The north-west part of Planty. To the right - the monument of Artur Grottger (painter) - photo A. Wagner

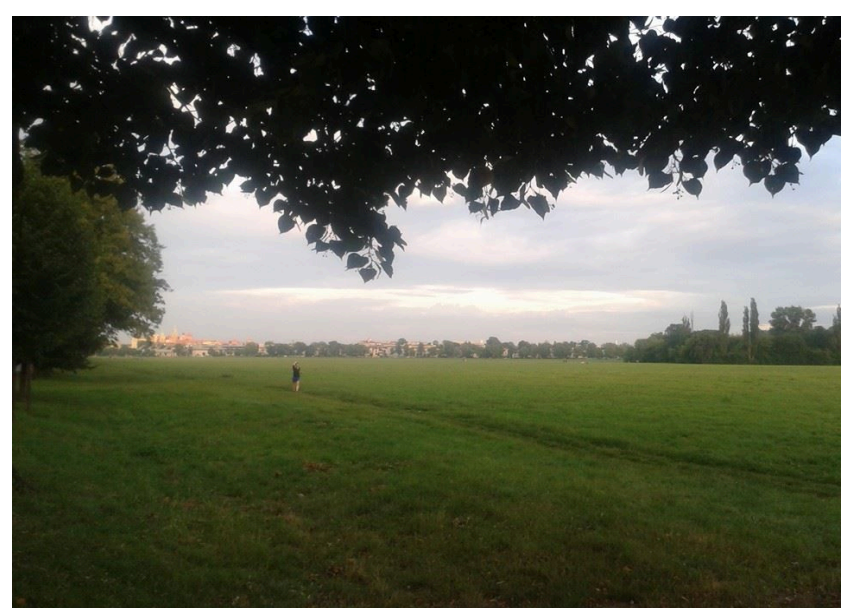

Figure 3. Błonia - a general view from the western side to the city centre, $14^{\text {th }}$ July, 2015 - photo A. Wagner

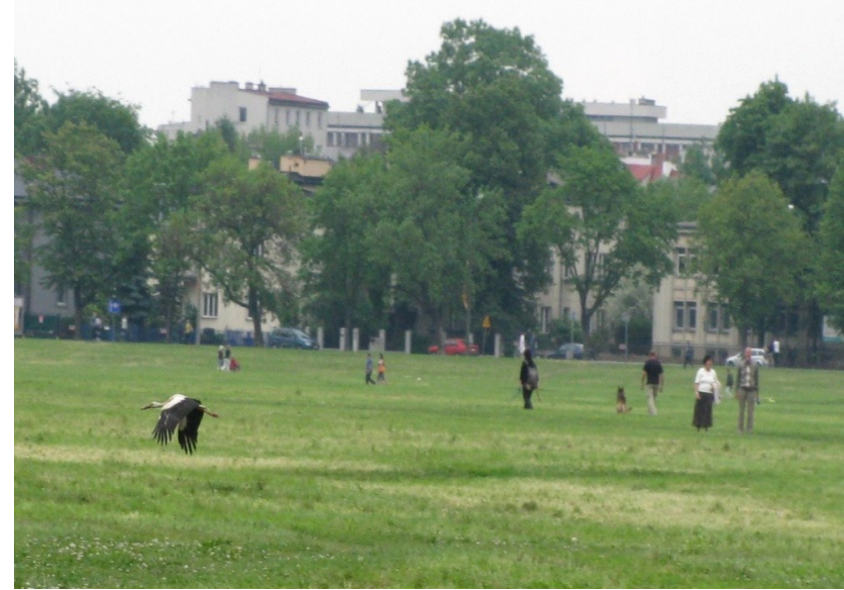

Figure 4. Błonia on $3^{\text {rd }}$ June 2012 - in the bottom-left part - a white stork Ciconia ciconia (Brisson) - photo A. Wagner

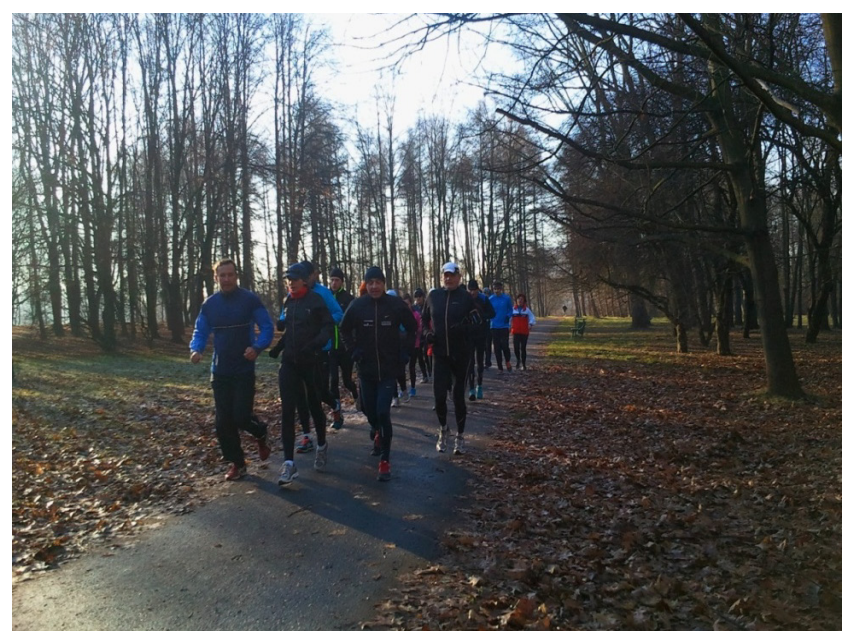

Figure 5. Students' training in the Park of the Polish Aviators - photo: M. Orlewicz-Musiał

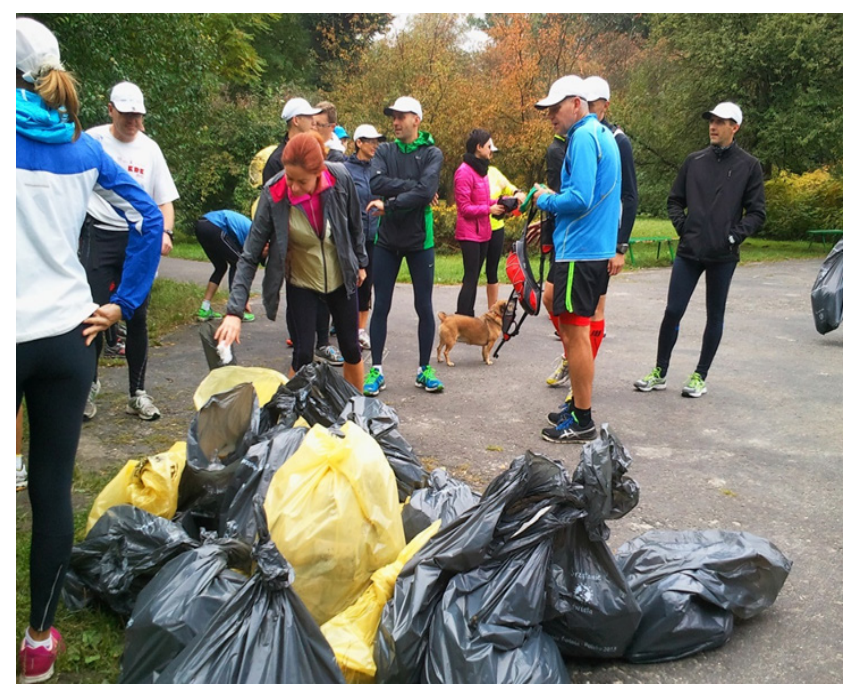

Figure 6. Students collect rubbish in the Park of the Polish Aviators photo: M. Orlewicz-Musiał 


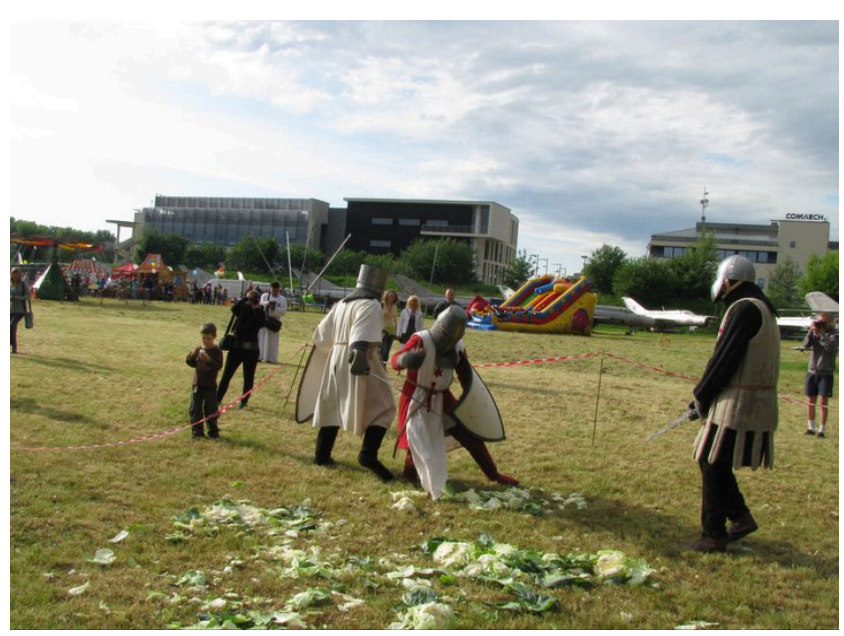

Figure 7. The Festival of Quarter XVIII, Czyżyny, $19^{\text {th }}$ June, 2011 - photo: A. Wagner

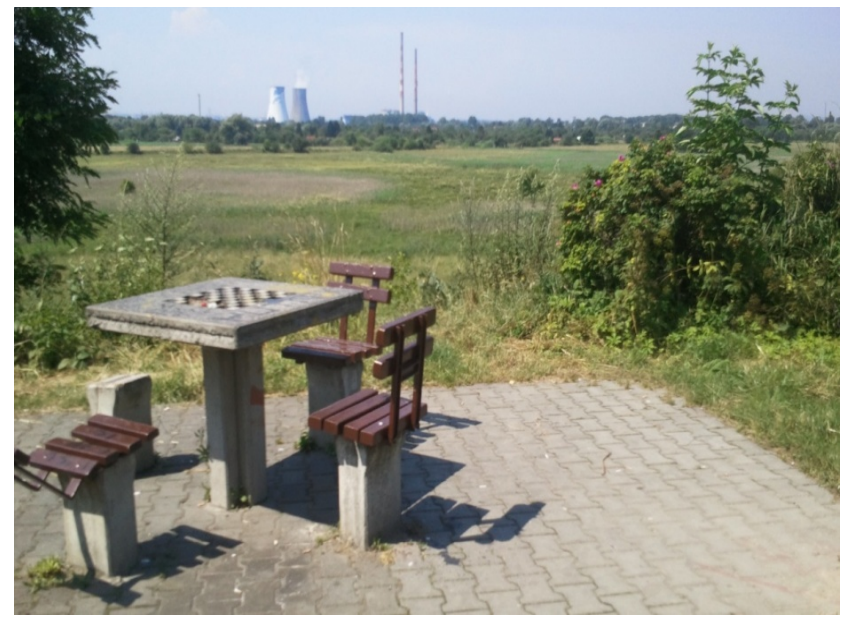

Figure 8. The Nowa Huta Meadows - photo: M. Orlewicz-Musiał

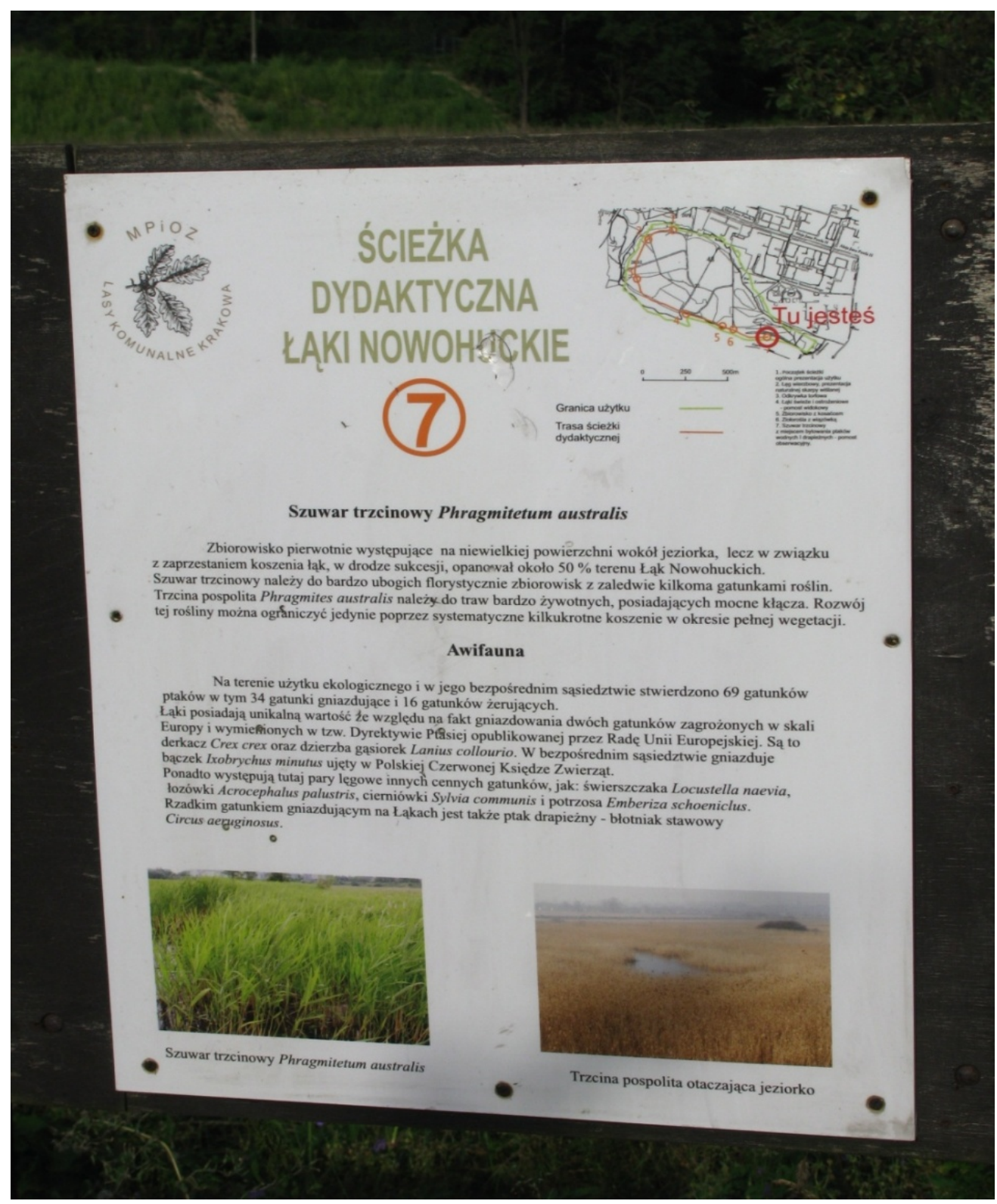

Figure 9. An information table from the didactic trail, informing about the reed habitat and the birds occurring in the Meadows - photo: A. Wagner 
Table 1. Age distribution among the questionnaire respondents; N- number (persons failing to provide data not included)

\begin{tabular}{|c|c|c|c|c|c|c|c|c|c|c|c|c|c|}
\hline \multirow{2}{*}{ Location - Respondents } & \multicolumn{2}{|c|}{ Below 25} & \multicolumn{2}{|c|}{$25-34$} & \multicolumn{2}{|c|}{$35-44$} & \multicolumn{2}{|c|}{$45-54$} & \multicolumn{2}{|c|}{$55-64$} & \multicolumn{2}{|c|}{$\begin{array}{c}65 \text { and } \\
\text { above }\end{array}$} & \multirow{2}{*}{$\frac{\text { Total }}{\mathrm{N}}$} \\
\hline & $\mathrm{N}$ & $\%$ & $\mathrm{~N}$ & $\%$ & $\mathrm{~N}$ & $\%$ & $\mathrm{~N}$ & $\%$ & $\mathrm{~N}$ & $\%$ & $\mathrm{~N}$ & $\%$ & \\
\hline Planty & 12 & 29.3 & 7 & 17.1 & 3 & 7.3 & 0 & 0 & 8 & 19.5 & 11 & 26.8 & 41 \\
\hline Błonia & 4 & 12.9 & 4 & 12.9 & 10 & 32,3 & 4 & 12.9 & 6 & 19.4 & 3 & 9.6 & 31 \\
\hline Park of Aviators & 1 & 4.0 & 7 & 28.0 & 5 & 20.0 & 1 & 4.0 & 5 & 20.0 & 6 & 24.0 & 25 \\
\hline NH Meadows & 12 & 40.0 & 7 & 23.3 & 1 & 3.3 & 2 & 6.7 & 2 & 6.7 & 6 & 20.0 & 30 \\
\hline Total & 29 & 22.8 & 25 & 19.7 & 19 & 15.0 & 7 & 5.5 & 21 & 16.5 & 26 & 20.5 & 127 \\
\hline
\end{tabular}

Table 2. The place of respondents' residence of the visitors of Nowa Huta

\begin{tabular}{|c|c|c|c|c|c|}
\hline & $\begin{array}{l}\text { Up to } 3 \mathrm{~km} \text { from } \\
\text { the place }\end{array}$ & $\begin{array}{c}\text { In Krakow - distance above } \\
3 \mathrm{~km}\end{array}$ & Krakow vicinity & More than $40 \mathrm{~km}$ from Krakow & Total \\
\hline Planty & $\begin{array}{c}15 \\
36.6 \% \\
\end{array}$ & $\begin{array}{c}16 \\
39.0 \% \\
\end{array}$ & $\begin{array}{c}2 \\
4.9 \% \\
\end{array}$ & $\begin{array}{c}8 \\
19.5 \% \\
\end{array}$ & $\begin{array}{c}41 \\
100 \% \\
\end{array}$ \\
\hline Błonia & $\begin{array}{c}13 \\
41.9 \% \\
\end{array}$ & $\begin{array}{c}15 \\
48.4 \% \\
\end{array}$ & $\begin{array}{c}1 \\
3.2 \% \\
\end{array}$ & $\begin{array}{c}2 \\
6.5 \% \\
\end{array}$ & $\begin{array}{c}31 \\
100 \% \\
\end{array}$ \\
\hline Total & 28 & 31 & 3 & 10 & 72 \\
\hline
\end{tabular}

Table 3. The place of respondents' residence of the visitors of Nowa Huta

\begin{tabular}{|c|c|c|c|c|c|}
\hline & Nowa Huta & Other Krakow's Quarter & Krakow vicinity & More than $40 \mathrm{~km}$ from Krakow & Total \\
\hline \multirow{2}{*}{ Park of Aviators } & 11 & 7 & 3 & 4 & 25 \\
& $44.0 \%$ & $28 \%$ & $12.0 \%$ & 4 & $16.0 \%$ \\
\hline \multirow{2}{*}{ NH Meadows } & 22 & 1 & 3 & $10.0 \%$ & $3.3 \%$ \\
\hline Total & $33.4 \%$ & $8.3 \%$ & 6 & 8 & $100 \%$ \\
\hline
\end{tabular}

Table 4. The respondents' assessment of different aspects of the four locations. the data of the Park of Aviators and the Nowa Huta Meadows taken from the previous paper [6]. The visitors were using scale $1-5$ ( 5 as the best). Highest values in bold, lowest in italics

\begin{tabular}{|c|c|c|c|c|}
\hline Location & Feature & The number of persons responding this question & Mean grade & $\begin{array}{c}\text { Mean assessment } \\
\text { of the place } \\
\text { (and rank in } \\
\text { brackets) }\end{array}$ \\
\hline \multirow{5}{*}{ Planty } & Accessibility & 39 & 4.67 & \multirow{5}{*}{$\begin{array}{c}3.97 \\
\text { (II) }\end{array}$} \\
\hline & Sports and Recreation Facilities & 26 & 3.27 & \\
\hline & Nature & 39 & 3.87 & \\
\hline & Interesting objects & 35 & 4.20 & \\
\hline & Cleanness and General Aesthetics & 38 & 3.84 & \\
\hline \multirow{5}{*}{ Błonia } & Accessibility & 31 & 4.48 & \multirow{5}{*}{$\begin{array}{c}3.822 \\
\text { (III) }\end{array}$} \\
\hline & Sports and Recreation Facilities & 29 & 4.10 & \\
\hline & Nature & 31 & 3.55 & \\
\hline & Interesting objects & 28 & 3.18 & \\
\hline & Cleanness and General Aesthetics & 31 & 3.80 & \\
\hline \multirow{5}{*}{ Park of Aviators } & Accessibility & 24 & 4.38 & \multirow{5}{*}{$\begin{array}{c}3.994 \\
\text { (I) }\end{array}$} \\
\hline & Sports and Recreation Facilities & 21 & 4.19 & \\
\hline & Nature & 23 & 4.13 & \\
\hline & Interesting objects & 21 & 3.19 & \\
\hline & Cleanness and General Aesthetics & 24 & 4.08 & \\
\hline \multirow{5}{*}{ NH Meadows } & Accessibility & 26 & 4.23 & \multirow{5}{*}{$\begin{array}{c}3.784 \\
\text { (IV) }\end{array}$} \\
\hline & Sports and Recreation Facilities & 25 & 3.88 & \\
\hline & Nature & 28 & 4.50 & \\
\hline & Interesting objects & 25 & 3.12 & \\
\hline & Cleanness and General Aesthetics & 16 & 3.19 & \\
\hline
\end{tabular}


Table 5. Leisure activities in the areas of Nowa Huta. In brackets the number of respondents is given. One respondent could indicate more than one possibility

\begin{tabular}{|c|c|c|c|c|c|c|}
\hline & Stroll & $\begin{array}{l}\text { Walking with } \\
\text { the dog }\end{array}$ & $\begin{array}{c}\text { Sitting } \\
\text { (on a bench) }\end{array}$ & Physical exercises & $\begin{array}{l}\text { Observation } \\
\text { of the nature }\end{array}$ & Other \\
\hline Planty (41) & $\begin{array}{c}31 \\
75.6 \%\end{array}$ & $\begin{array}{c}2 \\
4.9 \%\end{array}$ & $\begin{array}{c}36 \\
87.8 \%\end{array}$ & $\begin{array}{c}7 \\
17.1 \%\end{array}$ & $\begin{array}{c}12 \\
29.3 \%\end{array}$ & $\begin{array}{c}9 \\
22.0 \%\end{array}$ \\
\hline Błonia (31) & $\begin{array}{c}13 \\
41.9 \%\end{array}$ & $\begin{array}{c}6 \\
19.4 \%\end{array}$ & $\begin{array}{c}8 \\
25.8 \%\end{array}$ & $\begin{array}{c}21 \\
67.7 \%\end{array}$ & $\begin{array}{c}7 \\
22.6 \%\end{array}$ & $\begin{array}{c}3 \\
9.7 \%\end{array}$ \\
\hline Park of Aviators (25) & $\begin{array}{c}19 \\
76.0 \%\end{array}$ & 0 & $\begin{array}{c}15 \\
60.0 \%\end{array}$ & $\begin{array}{c}8 \\
32.0 \%\end{array}$ & $\begin{array}{c}10 \\
44.0 \%\end{array}$ & $\begin{array}{c}1 \\
4.0 \%\end{array}$ \\
\hline NH Meadows (30) & $\begin{array}{c}26 \\
86.7 \%\end{array}$ & $\begin{array}{c}11 \\
36.7 \%\end{array}$ & $\begin{array}{c}18 \\
60.0 \%\end{array}$ & $\begin{array}{c}11 \\
36.7 \%\end{array}$ & $\begin{array}{c}14 \\
46.7 \%\end{array}$ & $\begin{array}{c}2 \\
6.7 \%\end{array}$ \\
\hline
\end{tabular}

Table 6. What brought you here for the first time? In brackets the number of respondents is given One respondent could indicate more than one possibility

\begin{tabular}{|c|c|c|c|c|c|c|c|c|c|c|}
\hline & Cycling & Running & $\begin{array}{c}\text { Other } \\
\text { Exercises }\end{array}$ & $\begin{array}{l}\text { Coming } \\
\text { with } \\
\text { children }\end{array}$ & Event & Schooll/Work & $\begin{array}{c}\text { I } \\
\text { live } \\
\text { here }\end{array}$ & Accidentally & $\begin{array}{l}\text { I don't } \\
\text { remember }\end{array}$ & Other \\
\hline $\begin{array}{c}\text { Planty } \\
(41)\end{array}$ & $\begin{array}{c}3 \\
7 \%\end{array}$ & $\begin{array}{c}6 \\
15 \%\end{array}$ & $\begin{array}{c}2 \\
5 \%\end{array}$ & $\begin{array}{c}7 \\
17 \%\end{array}$ & $\begin{array}{c}1 \\
2 \%\end{array}$ & $\begin{array}{c}1 \\
2 \%\end{array}$ & $\begin{array}{c}1 \\
2 \%\end{array}$ & $\begin{array}{c}10 \\
24 \%\end{array}$ & $\begin{array}{c}7 \\
17 \%\end{array}$ & $\begin{array}{c}17 \\
41 \%\end{array}$ \\
\hline $\begin{array}{c}\text { Błonia } \\
\text { (31) }\end{array}$ & $\begin{array}{c}6 \\
19 \%\end{array}$ & $\begin{array}{c}6 \\
19 \%\end{array}$ & $\begin{array}{c}7 \\
23 \%\end{array}$ & $\begin{array}{c}5 \\
16 \%\end{array}$ & $\begin{array}{c}8 \\
26 \%\end{array}$ & $\begin{array}{c}1 \\
3 \%\end{array}$ & $\begin{array}{c}1 \\
3 \%\end{array}$ & $\begin{array}{c}6 \\
19 \%\end{array}$ & $\begin{array}{c}1 \\
3 \%\end{array}$ & $\begin{array}{c}7 \\
23 \%\end{array}$ \\
\hline $\begin{array}{l}\text { PA } \\
(25)\end{array}$ & $\begin{array}{c}7 \\
28 \%\end{array}$ & $\begin{array}{c}4 \\
16 \%\end{array}$ & $\begin{array}{c}1 \\
4 \%\end{array}$ & $\begin{array}{c}4 \\
16 \%\end{array}$ & 0 & 0 & $\begin{array}{c}4 \\
16 \%\end{array}$ & $\begin{array}{c}4 \\
16 \%\end{array}$ & $\begin{array}{c}1 \\
4 \%\end{array}$ & $\begin{array}{c}3 \\
12 \%\end{array}$ \\
\hline $\begin{array}{l}\text { NHM } \\
(30)\end{array}$ & $\begin{array}{c}9 \\
30 \%\end{array}$ & $\begin{array}{c}6 \\
20 \%\end{array}$ & $\begin{array}{c}4 \\
13 \%\end{array}$ & $\begin{array}{c}2 \\
7 \%\end{array}$ & $\begin{array}{c}6 \\
20 \%\end{array}$ & $\begin{array}{c}8 \\
27 \%\end{array}$ & $\begin{array}{c}11 \\
37 \%\end{array}$ & $\begin{array}{c}7 \\
23 \%\end{array}$ & $\begin{array}{c}1 \\
3 \%\end{array}$ & $\begin{array}{c}4 \\
13 \%\end{array}$ \\
\hline
\end{tabular}

\section{Discussion}

The results confirm that green areas have a very wide variety of functions, which creates a great potential for the education for sustainable development. The questionnaires focused on social, wellbeing and environmental aspects of sustainable development rather than on economic aspects. The reason for this is that in the aspects of development usually economic issues are treated as the most important, so here the authors wanted to focus on other aspects. The results show the importance of green areas as well as relatively high grades giving in the evaluation of different aspects.

Previous studies on Planty and Błonia were done by Hulicka [21] who named functions of these areas and carried out a questionnaire. Her results indicate recreational, social, tourist, didactic, artistic, health-related and aesthetic function of Planty and the questionnaire indicates resting and social meetings as the main functions, while sport and active recreation are treated as marginal functions. Our questionnaire confirms these findings. Nevertheless one has to bear in mind that it was carries out in hot Sunday afternoon during holidays. Other author's observations show that early morning the park is visited by runners and Nordic walkers. There are also sports events organized around the city and attended by thousands of people. These events are often commercial and combine economic and social aspects of sustainable development. The combination of historical and ecological value of Planty makes the area a perfect place for education at any educational level. Biology, history and also literature classes (because of the monuments of literature characters) can be held there.

Hulicka [21] gives the following functions of Błonia: sport, recreational, religious, didactic and educational as well as health-related. The respondents of the questionnaire showed sport, social meetings and recreation as the main functions of Błonia. This was confirmed by our questionnaire. Events strictly related to the education for sustainable development are Recycling Festivals. Also social role of Błonia is contributing to sustainable development. One of big sports events is Cracovia Marathon organized since 2002 [9]. Apart sports character it is also a commercial event. There is a project to improve street lights in an alley in the southern part of the Błonia so that the area could be safer and available for sports also at night [22].

Our questionnaires in Nowa Huta showed that the most important role in the education for sustainable development is played by the Nowa Huta Meadows, however the Park of Aviators was better assessed in terms of accessibility, sports and recreation facilities, the presence of interesting objects 
and cleanness. This could be confirmed by our own observations, however the function of ecologically useful area often contradicts with building too much infrastructure. There are often contradicting expectations of the visitors. Some would like to keep the area "tidy" and some would prefer a "wilder" character. The example can be mowing. Too frequent mowing can destroy bird habitats. On the other hand the lack of mowing would allow natural succession and complete change of habitat.

Three of the studied areas are formally protected, two as historical monuments and one (the Nowa Huta Meadows) as environmentally useful area. The Park of Aviators is not formally protected and there are attempts to increase the development in that area (car parks) near the indoor arena. This will improve the access and probably make the park more attractive, nevertheless care should be taken not to contribute to the shrinking of green areas too much. The Park has already received the highest overall grade in the questionnaire evaluation. The revitalization project [15] gives a chance for further improvement of the quality of this area without changing the character of the place.

Pro-environmental education is the most developed at the Nowa Huta Meadows. Information tables are well explaining the habitat and species composition there. Planty, Błonia and the Park of Aviators are lacking such tables or the information such as the names of trees and possible tables with birds would be very useful. Historical and natural values are not contradicted. The example can be the information tables in Forum Romanum (Rome, Italy) author's observation of May 2005. The comparison between different aspects of sustainable development in the four studied localities is given in table 7 . In this table there are also proposals for the improvements towards better implementation of sustainable development.

Table 7. Different aspects of sustainable development and education in the four green areas of Krakow.

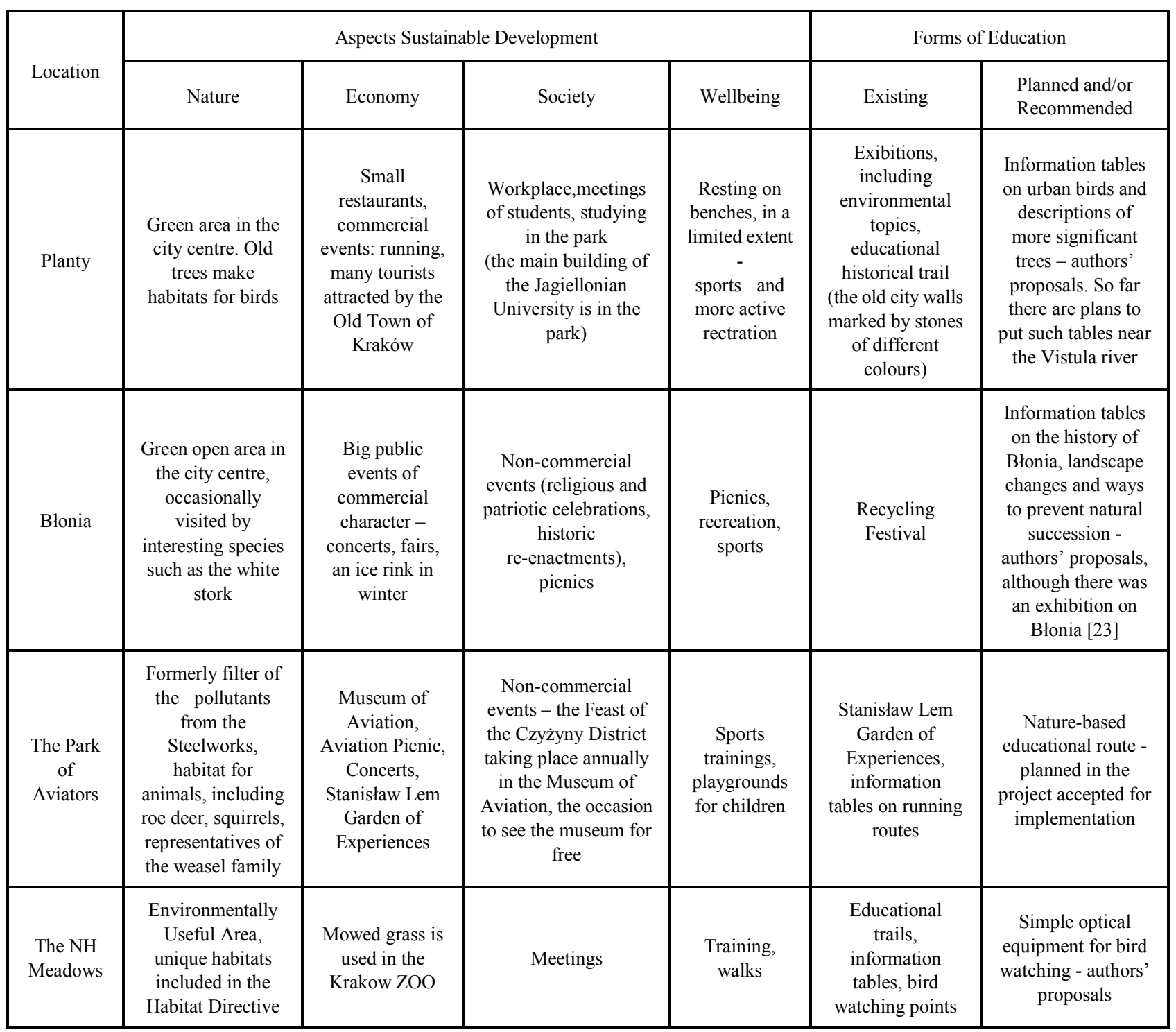




\section{Conclusions}

1. All the four studied objects play important role in all the aspects of sustainable development: environmental, economic, social and wellbeing, however the social and wellbeing aspect is best visible.

2. The educational value of green areas manifests in mass events of educational character, such as the Earth Day and the Recycling Festival, as well as activities carried out individually or in smaller groups (e.g. bird watching).

3. One of the studied objects (the Nowa Huta Meadows) is covered by official protection as the ecologically useful area. This area is the most related to the education for sustainable development, although often seen as "untidy".

4. Two objects (Planty, Błonia) are registered as historical monuments.

5. The questionnaires among the visitors of the areas show that the respondents appreciate the green areas in question. They find it easy to reach these areas. Each area is seen in a different way: Planty mainly as the place of resting in a passive way, the three other areas more as places of sports activities

6. Information tables about wildlife and vegetation occur in the Nowa Huta Meadows, but not in other locations. They are planned in the Park of Aviators. The authors recommend similar tables in two other locations.

\section{Acknowledgements}

The paper was partially supported by grant Badania Statutowe AGH 11.11.150.949/15.

The Authors wish to thank Mr. Michał Franczyk - the Member of the Council of the City District Czyżyny for his valuable information. We also wish to thank all the respondents of the questionnaires.

\section{REFERENCES}

[1] A. Pawłowski, Rozwój zrównoważony - idea, filozofia, praktyka. Monografie Komitetu Inżynierii Środowiska PAN, vol. 51, Lublin, 2008.

[2] A. AtKisson, The ISIS Agreement. How sustainability can improve organizational performance and transform the world, Earthscan, London, 2008.

[3] E. Barucka, W szkatułach zieleni. Europejski Ruch Miast Ogrodów 1903-1930. WUW, Warszawa, 2014.

[4] A. Wagner, B. Patuła, Ekologiczna i społeczna rola ogródków działkowych na przykładzie ogrodów „Małe Błonia” i „Aster” w Krakowie, in: Ogrody działkowe w miastach bariera czy wartość? (ed. M. Kosmala), Polskie Zrzeszenie Inżynierów i Techników Sanitarnych. Oddział Toruń, Toruń, 143-149, 2013.
[5] A. Delorme, Antyekologiczna spuścizna totalitaryzmu: polityka, gospodarka, środowisko naturalne, "Secesja", Kraków, 1995.

[6] M. Orlewicz-Musiał, A. Wagner, Przeobrażenia terenów zieleni miejskiej $\mathrm{w}$ związku $\mathrm{z}$ rozwojem infrastruktury sportowo-rekreacyjnej na przykładzie dzielnic Nowej Huty w Krakowie, in: Kierunki zmian terenów zieleni w miastach, ed. M. Kosmala. Toruń, Polskie Zrzeszenie Inżynierów i Techników Sanitarnych. Oddział Toruń, 241-252, 2014.

[7] J. Torowska: Planty Krakowskie i ich przestrzeń kulturowa, Seria Parki Krakowa, Ośrodek Kultury im. Cypriana K. Norwida, Kraków, 2012. Online available: http://jbc.bj.uj.edu.pl/Content/256234/Planty\%20Krakowski e\%20i\%20ich\%20przestrzen\%20kulturowa.pdf (access $8 / 06 / 2015)$

[8] ZESPOŁY I OBIEKTY Z TERENU MIASTA KRAKOWA WPISANE DO REJESTRU ZABYTKÓW ( Stan maj 2015 r.), 2015. Online available:

http://www.wuoz.malopolska.pl/index.php?option=com con tent\&task=view\&id=23\&Itemid=47 (access 17/08/2015).

[9] M. Orlewicz-Musiał, A. Wagner, Rola terenów zieleni w zrównoważonym rozwoju miasta na przykładzie Błoń Krakowskich i Parku im. Dr Henryka Jordana w Krakowie, in: Zieleń a klimat społeczny miasta (ed. M. Kosmala), Torun, Polskie Zrzeszenie Inżynierów i Techników Sanitarnych. Oddział, 147-158, 2012.

[10] A. Chwalba, Okupacyjny Kraków w latach 1939-1945. Wydawnictwo Literackie, Kraków, 2011.

[11] Cykliczne akcje edukacyjne - Edukacja ekologiczna : EkoCentrum - Czysty Kraków Lepsze Życie. Online available:

http://www.ekocentrum.krakow.pl/585,a,cykliczne-akcje-ed ukacyjne.htm (access 9/06/2015)

[12] Council Directive 79/409/EEC of 2 April 1979 on the conservation of wild birds

[13] Stanislaw Lem Garden of Experiences. Online available: http://www.ogroddoswiadczen.pl/en (access 16/07/2015)

[14] R. Kulig: Wyniki głosowania na Budżet Obywatelski Krakowa. 2015. Online available:

http://wiadomosci.wp.pl/kat,140688,title,Wyniki-glosowania -na-Budzet-Obywatelski-Krakowa,wid,17687716,wiadomos c.html (access 16/07/2015)

[15] Oznakowanie ścieżek biegowych w Parku Lotników Polskich. Online available:

http://budzet.dialoguj.pl/projects/910-oznakowanie-sciezekbiegowych-w-parku-lotnikow-polskich (access 17/07/2015)

[16] Park Lotników. Apartamenty. Lokalizacja. Online available: http://www.parklotnikow.pl/lokalizacja (access 17/07/2015)

[17] Miejski Park i Ogród Zoologiczny w Krakowie. Online available: http://www.zoo-krakow.pl/doc.php?group $=32$ (access 17/07/2015)

[18] Magiczny Kraków - Kraków eko.LIDEREM. Online available:

http://krakow.pl/aktualnosci/156962,34,komunikat,krakow_e ko_liderem.html (access 9/06/2015)

[19] Dni Ziemi - Cykliczne akcje edukacyjne - Edukacja ekologiczna : EkoCentrum - Czysty Kraków Lepsze Życie, 
Online available:

http://www.ekocentrum.krakow.pl/586,a,dni-ziemi.htm (access 10/06/2015)

[20] E. Dubiel, J. Szwagrzyk et al. (ed.), Atlas roślinności rzeczywistej Krakowa, Urząd Miasta Krakowa, Wydział Kształtowania Środowiska, Kraków, 2008.

[21] A. Hulicka, Funkcje zabytkowych parków miejskich na przykładzie Krakowa, in: Zieleń a klimat społeczny miasta
(M. Kosmala - ed.), Toruń, 247-260, 2012.

[22] Budowa oświetlenia alejki spacerowo-rowerowej na Błoniach wzdłuż al. Focha. 2015

http://budzet.dialoguj.pl/projects/659-budowa-oswietlenia-al ejki-spacerowo-rowerowej-na-bloniach-wzdluz-al-focha (access 17/07/2015)

[23] Historical Museum of the City of Krakow. 2015 http://www.mhk.pl/exhibitions/238 (access 17/07/2015) 